\title{
Analysis using multi-criteria decision making to evaluate smart phone alternatives within the global supply
}

\author{
Alena Pozdílková ${ }^{1, *}$, Martina Hedvičáková ${ }^{2}$, and Nikola Jačková1 \\ ${ }^{1}$ University of Pardubice, Faculty of Electrical Engineering and Informatics, Studentská 95, 53210 \\ Pardubice, Czech Republic \\ ${ }^{2}$ University of Hradec Králové, Faculty of Economics and Management, Rokitanského, 50003 Hradec \\ Králové 62, Czech Republic
}

\begin{abstract}
Research background: In terms of the development of information and communication technologies, smart mobile phones are booming. Consumers choose the most suitable smartphone concerning their needs and preferences. Consumers are not limited by the domestic supply but can choose from smartphones from all over the world. The article aims to provide effective multi-criteria decision-making to evaluate different mobile phones according to consumer preferences of global supply.

Purpose of the article: The benefit of the article is the elimination of uncertainty in the choice of mobile phone and the expression of preferences of the consumer with decision-making powers.

Methods: Multicriteria decision-making is based on the evaluation of the possibilities of mobile phones with regard to the preferences of users. Ordinalistic (Lexicographic method and ORESTE method) and Cardinalistic method (TOPSIS method and Weighted sum method) are used for this evaluation.

Findings \& Value added: Based on the methods used, the variants of smartphones were ranked from best to worst. The order differed significantly for the selected methods. The lexicographic method recommended buying the cheapest variant. The ORESTE method recommended buying one of the most expensive variants. Of the methods requiring cardinal information, the TOPSIS method in the model example recommended the purchase of the Realme $7 \mathrm{i}$ variant and the weighted sum method recommended the purchase of the Samsung Galaxy A52 variant despite its high price. All results are calculated using a decision support system. The application contains a DLL library that provides the decision-making process and the structure of the decision-making problem and the user environment.
\end{abstract}

Keywords: multi-criteria decision making, ordinal information, cardinal information, mobile phone, global supply

JEL Classification: $E 43, G 21, G 11$

\footnotetext{
* Corresponding author: alena.pozdilkova@upce.cz
} 


\section{Introduction}

Rapid advances in mobile communication technologies, especially the adoption of the mobile phone in every-day life, make up many companies to market different types of mobile phones. Furthermore, advances in technology directly affect users' access to other phones. In this study, the social and cultural side of cell phone adoption were skipped. The important choice is the list of criteria and their preferences (Işiklar \& Büyüközkan, 2007).

The authors (Lee et al., 2006) assume that user satisfaction depends on the product design and create relation-ship models based on experimental data to predict user satisfaction and provide important data for corrective actions for design change. In further studies, the authors (Chang et al., 2010; Han et al., 2004; Işiklar \& Büyüközkan, 2007; Plos \& Buisine, 2006) attempted to explore the relationship between user preferences of mobile phones and their design elements. Other authors (Mourtzis et al., 2017) point to the need to adapt quickly and effectively to the rapidly changing demands of the market, which are affected by globalization, economic instability and customer needs towards greater product diversity.

Consumer decision-making style can be defined "as a mental orientation characterizing a consumer's approach to making choices (Stankevich, 2017)" (Sproles and Kendall, 1986, p. 267). (Lysonski et al., 1996). The chosen methods are popular for multiple criteria decision making. They have gained their popularity, especially for their good traceability, mathematical simplicity and usability for many different types of decision problems (Zapletal, 2020).

\section{Methodology}

The subject of the purchase decision making was chosen for several reasons. Above all, everyone plays the role of a consumer and makes a lot of shopping decisions every day. It is important to understand what influences personal purchasing decisions. Is it a problem or a need or even a marketing campaign? In addition, it is valuable from a trader's / manufacturer's perspective to know this topic in order to effectively target customers, improve a company's products and services, and understand how customers view products over competing products. Based on this, the total utility of the consumer grows and consumers get a product with higher utility value, better features or service, which will lead to increased overall customer satisfaction and gain a competitive advantage for manufacturers (Stankevich, 2017).

The aim of the article is to select the most suitable mobile phone for consumers based on a multi-criteria analysis. Multicriteria decision-making is based on the evaluation of the possibilities of mobile phones with regard to the preferences of users. First, the most popular functions influencing the choice of mobile phone are identified. This is achieved through a survey among the target group, the experience of experts in the telecommunications sector and studies in the literature (Büyüközkan \& Güleryüz, 2016; Işiklar \& Büyüközkan, 2007). Two groups of methods are then used in the evaluation process. Methods that require ordinal information (lexicographic method and ORESTE method) and methods that require cardinal information (TOPSIS method and weighted sum method) will be used for evaluation.

The initial step for multi-criteria evaluation of variants with certainty is usually the determination of individual weights of criteria. The weight of the criterion numerically expresses the significance of this criterion, where it is generally true that the higher the rating, the higher the significance. There are several methods for determining the weights of the criteria. The weights of the criteria are expressed in the interval $<0.1>$ and their sum must be equal to one, so the last step in determining them is to normalize the individual weights. The result of the methods of determining the weights is a weight vector (Bažant, 2009; Brožová et al., 2003). 
The following chapters will describe the two most important ways of determining compromise options.

\subsection{Methods with ordinal information}

To use methods that work with ordinal information about criteria and / or variants, it is required to specify the order of importance of the criteria and the order of variants. The representative of this type of methods is the lexicographic method and the ORESTE method. The lexicographic method is one of the simple procedures for solving multicriteria decisionmaking. Its principle is that the most important criterion has the greatest influence on the choice of variant. If there are several variants that are evaluated equally in the most important criterion, they are compared according to the second most important criterion, etc. The disadvantage of this approach is the complete neglect of the values of the least important criteria (Brožová et al., 2003; Fiala et al., 2008).

When using the ORESTE method, the decision-maker is required to complete a quasiarrangement of criteria and variants according to individual criteria. The ORESTE method is divided into two parts (Brožová et al., 2003). In the first part, the distance of each variant is determined according to individual criteria from the fictitious beginning, where the fictitious variant and the fictitious criterion are evaluated with the value 0 . The next step is to arrange the variants according to certain rules (Brožová et al., 2003). A vector that expresses the sequence numbers of the criteria, where the indifferent criteria are evaluated by average sequence numbers, is denoted as $q=\left(q_{1}, q_{2}, \ldots, q_{n}\right)$. The arrangement of variants according to individual criteria is expressed by means of the matrix $P=\left(p_{i j}\right), \mathrm{i}=1,2, \ldots, \mathrm{m}, \mathrm{j}=1,2$, $\ldots, \mathrm{n}$. Using Dujmič's metric, the matrix D is calculated, whose elements $d_{i j}$ express the distance from the fictitious origin $p_{0 j}=(0,0, \ldots 0)$ :

$$
d_{i j}=\left(0,5\left(p_{i j}\right)^{r}+0,5\left(q_{j}\right)^{r}\right)^{\frac{1}{r}} i=1,2, \cdots m, j=1,2, \cdots, n
$$

where the number $r$ is a real number. As a rule, the value of this number is around the value 3. The calculated distances $d_{i j}$ are then arranged in ascending order and evaluated by serial numbers rij or, in the case of the same values, evaluated by average serial numbers. From the resulting matrix $R=\left(r_{i j}\right)$ we determine for each row its sum $r_{i}$. The quasi-arrangement of variants is obtained by ascending order of $r_{i}$ values. The second part of the method contains a preferential analysis, thanks to which it is possible to determine for each pair of variants their preferences $\mathrm{P}$, indifference I and incomparability $\mathrm{N}$. This method is described in more detail in (Brožová et al., 2003).

\subsection{Methods with cardinal information}

For methods requiring cardinal information, the solver must have a vector of criteria weights and a criterion matrix to solve. We will focus on the weighted sum method and the TOPSIS method.

The weighted sum method (WSA) can be used both to find the best possible variant and to arrange the set of variants according to importance, as it creates an overall rating for each of the variants (Brožová et al., 2003). The method is based on the principle of maximizing utility, ie. that the value of the benefit that the choice of variant will bring is determined. The utility is expressed by the value from the scale 0 to 1 , where the higher the value, the better the variant (Fiala et al., 2008)

The first step is to create a criterion matrix $R=\left(r_{i j}\right)$, the elements of which are obtained using the formula 


$$
r_{i j}=\frac{y_{i j}-d_{j}}{h_{j}-d_{j}}
$$

where $h_{j}$ represents the evaluation of the $\mathrm{j}$-th element in the determined ideal variant $\mathrm{H}$ and where $d_{j}$ represents the evaluation of the $\mathrm{j}$-th element in the determined basal variant $\mathrm{D}$. The elements of the matrix $\mathrm{R}$ then represent the values of the utility function of individual variants according to individual criteria.

The total utility of variant $a_{i}$ is calculated according to

$$
u\left(a_{i}\right)=\sum_{j=1}^{n} v_{j} r_{i j} .
$$

The variant with the highest value of $u\left(a_{i}\right)$ is the best variant sought, or by descending order of variants according to the values of $u\left(a_{i}\right)$ we obtain an ordered set of variants (Brožová et al., 2003).

The TOPSIS method uses the distance of individual variants from the ideal and basal variants to solve decision-making problems. The best variant has the smallest distance from the ideal variant and the greatest distance from the basal variant. The method also offers a complete arrangement of a set of variants, so it is suitable for solving tasks that require the order of variants. To use the method, it is necessary to convert all minimization criteria to maximization by multiplying them by the constant -1 . This method is described in more detail in (Brožová et al., 2003).

\section{Application and results}

To demonstrate the results of individual methods, a model example of mobile phone selection was chosen. The decision-maker, who is also the contracting authority, identified a total of seven criteria according to which the decision will be made. The maximum, resp. the minimum values that the variants must acquire. The list of criteria and their maximum and minimum values is as follows:

- $\quad$ maximum price of CZK 10,000,

- camera resolution of at least 48 Mpix,

- user memory of at least $64 \mathrm{~GB}$,

- RAM of at least $4096 \mathrm{MB}$,

- minimum version of the Android 8 operating system,

- $\quad$ maximum weight $210 \mathrm{~g}$,

- battery capacity at least $4500 \mathrm{mAh}$.

The decision maker will use the mobile phone for photography, so the camera's resolution and the phone's memory are decisive for him. An important criterion is also the price of the mobile phone, the version of the operating system, its weight and battery capacity. Processor frequency or display resolution are not decisive criteria for decision makers due to the intended use of the phone. Based on the above parameters, a total of five mobile phones were selected. The name of the mobile phone and the monitored parameters are listed in the following table.

Table 1. Monitored parameters of mobile phones.

\begin{tabular}{|l|r|r|r|r|r|r|c|}
\hline $\begin{array}{l}\text { Type of } \\
\text { mobile phone }\end{array}$ & Price & $\begin{array}{c}\text { Camera } \\
\text { resolution }\end{array}$ & $\begin{array}{c}\text { User } \\
\text { memory }\end{array}$ & RAM & $\begin{array}{c}\text { OS } \\
\text { version }\end{array}$ & Weight & $\begin{array}{c}\text { Battery } \\
\text { capacity }\end{array}$ \\
\hline $\begin{array}{l}\text { Samsung } \\
\text { Galaxy A42 }\end{array}$ & $\begin{array}{r}8990 \\
\text { Kč }\end{array}$ & $48 \mathrm{Mpix}$ & $128 \mathrm{~GB}$ & $\begin{array}{r}6144 \\
\mathrm{MB}\end{array}$ & 10 & $193 \mathrm{~g}$ & $5000 \mathrm{mAh}$ \\
\hline $\begin{array}{l}\text { Xiaomi Mi } \\
\text { Note 10 Lite }\end{array}$ & $\begin{array}{r}7390 \\
\text { Kč }\end{array}$ & $64 \mathrm{Mpix}$ & $64 \mathrm{~GB}$ & $\begin{array}{r}6144 \\
\mathrm{MB}\end{array}$ & 10 & $204 \mathrm{~g}$ & $5260 \mathrm{mAh}$ \\
\hline
\end{tabular}




\begin{tabular}{|l|r|r|r|r|r|r|r|}
\hline $\begin{array}{l}\text { Xiaomi } \\
\text { Redmi Note } \\
10\end{array}$ & $\begin{array}{r}5490 \\
\text { Kč }\end{array}$ & 48 Mpix & $128 \mathrm{~GB}$ & $\begin{array}{r}4096 \\
\mathrm{MB}\end{array}$ & 11 & $179 \mathrm{~g}$ & $5000 \mathrm{mAh}$ \\
\hline Realme 7i & $\begin{array}{r}3299 \\
\text { Kč }\end{array}$ & $48 \mathrm{Mpix}$ & $64 \mathrm{~GB}$ & $\begin{array}{r}4096 \\
\mathrm{MB}\end{array}$ & 10 & $208 \mathrm{~g}$ & $6000 \mathrm{mAh}$ \\
\hline $\begin{array}{l}\text { Samsung } \\
\text { Galaxy A52 }\end{array}$ & $\begin{array}{r}8990 \\
\text { Kč }\end{array}$ & $64 \mathrm{Mpix}$ & $128 \mathrm{~GB}$ & $\begin{array}{r}6144 \\
\mathrm{MB}\end{array}$ & 11 & $189 \mathrm{~g}$ & $4500 \mathrm{mAh}$ \\
\hline
\end{tabular}

All data in the following table were obtained using the information in Heureka (Heureka, 2021) in January 2021. The prices are the prices stated for the given mobile phone in the online store of the retailer of electronic goods DATART (Datart, 2021). The criteria were evaluated by the scoring method and standardized, see the following table.

Table 2. Standardized weights of individual criteria

\begin{tabular}{|l|r|}
\hline Criterion & Standardized weight \\
\hline Price & 0,21739 \\
\hline Camera resolution & 0,19565 \\
\hline User memory & 0,15217 \\
\hline RAM & 0,17391 \\
\hline OS version & 0,06522 \\
\hline Weight & 0,1087 \\
\hline Battery capacity & 0,08696 \\
\hline
\end{tabular}

We converted the values to minimization criteria, see the following table

Table 3. Matrix with converted values in minimization criteria

\begin{tabular}{|l|r|r|r|r|r|r|r|}
\hline $\begin{array}{l}\text { Type of } \\
\text { mobile phone }\end{array}$ & Price & $\begin{array}{c}\text { Camera } \\
\text { resolution }\end{array}$ & \multicolumn{1}{c|}{$\begin{array}{c}\text { User } \\
\text { memory }\end{array}$} & RAM & \multicolumn{1}{c|}{$\begin{array}{c}\text { OS } \\
\text { version }\end{array}$} & Weight & $\begin{array}{c}\text { Battery } \\
\text { capacity }\end{array}$ \\
\hline $\begin{array}{l}\text { Samsung } \\
\text { Galaxy A42 }\end{array}$ & -8990 & 48 & 128 & 6144 & 10 & -193 & 5000 \\
\hline $\begin{array}{l}\text { Xiaomi Mi } \\
\text { Note 10 Lite }\end{array}$ & -7390 & 64 & 64 & 6144 & 10 & -204 & 5260 \\
\hline $\begin{array}{l}\text { Xiaomi } \\
\text { Redmi Note } \\
10\end{array}$ & -5490 & 48 & 128 & 4096 & 11 & -179 & 5000 \\
\hline Realme 7i & -3299 & 48 & 64 & 4096 & 10 & -208 & 6000 \\
\hline $\begin{array}{l}\text { Samsung } \\
\text { Galaxy A52 }\end{array}$ & -8990 & 64 & 128 & 6144 & 11 & -189 & 4500 \\
\hline
\end{tabular}

The results of all four implemented methods will be presented below.

\subsection{Lexicographic method}

Using the lexicographic method, the variants were sorted:

1. Realme $7 \mathrm{i}$,

2. 2. Xiaomi Redmi Note 10,

3. Xiaomi Mi Note 10 Lite,

4. Samsung Galaxy A52,

5. Samsung Galaxy A42. 
The decisive criterion was the price criterion, so the application recommended buying the cheapest Realme 7i mobile phone. In the case of Samsung mobile phones, which have the same price, the order was determined by the second most important criterion - the resolution of the camera.

\subsection{ORESTE method}

The order of individual variants by the Oreste method looks like this:

Table 4. Rated matrix with row sums

\begin{tabular}{|c|c|c|c|c|c|c|c|c|}
\hline $\begin{array}{l}\text { Type of } \\
\text { mobile } \\
\text { phone }\end{array}$ & Price & $\begin{array}{l}\text { Camera } \\
\text { resolution }\end{array}$ & $\begin{array}{c}\text { User } \\
\text { memory }\end{array}$ & RAM & $\begin{array}{c}\text { OS } \\
\text { version }\end{array}$ & Weight & $\begin{array}{l}\text { Battery } \\
\text { capacity }\end{array}$ & SUM \\
\hline $\begin{array}{l}\text { Samsung } \\
\text { Galaxy } \\
\text { A42 }\end{array}$ & 15,5 & 11,5 & 11,5 & 7 & 34 & 21 & 28,5 & 129 \\
\hline $\begin{array}{l}\text { Xiaomi } \\
\text { Mi Note } \\
10 \text { Lite }\end{array}$ & 5 & 3,5 & 22,5 & 7 & 34 & 24 & 26 & 122 \\
\hline $\begin{array}{l}\text { Xiaomi } \\
\text { Redmi } \\
\text { Note } 10 \\
\end{array}$ & 2 & 11,5 & 11,5 & 17,5 & 31,5 & 19 & 28,5 & 121,5 \\
\hline Realme $7 \mathrm{i}$ & 1 & 11,5 & 22,5 & 17,5 & 34 & 27 & 25 & 138,5 \\
\hline $\begin{array}{l}\text { Samsung } \\
\text { Galaxy } \\
\text { A52 }\end{array}$ & 15,5 & 3,5 & 11,5 & 7 & 31,5 & 20 & 30 & 119 \\
\hline
\end{tabular}

The order of variants when using the ORESTE method is:

1. Samsung Galaxy A52,

2. Xiaomi Redmi Note 10,

3. Xiaomi Mi Note 10 Lite,

4. Samsung Galaxy A42,

5. Realme 7 i.

\subsection{TOPSIS method}

Using the TOPSIS method, a normalized weighted criterion matrix is calculated.

After determining the ideal variant $\mathrm{h}=(-0,04471,0,10189,0,08819,0,03082,-0,04465$, $0,04509)$ and the basal variant $\mathrm{d}=(-0,12184,0,07641,0,04067,0,05879,0,02801,-0,05188$, $0,03382)$ the distances from these vari-ants are calculated and then the relative index according to which the variants are sorted.

Table 5. Evaluation of variants by distances

\begin{tabular}{|l|r|r|r|}
\hline Type of mobile phone & Distance d+ & Distance d- & \multicolumn{1}{c|}{ Relative index } \\
\hline Samsung Galaxy A42 & 0,0817 & 0,05046 & 0,38182 \\
\hline Xiaomi Mi Note 10 Lite & 0,06932 & 0,04491 & 0,39313 \\
\hline Xiaomi Redmi Note 10 & 0,04951 & 0,06307 & 0,56025 \\
\hline Realme 7i & 0,05681 & 0,07795 & 0,57845 \\
\hline Samsung Galaxy A52 & 0,07799 & 0,05654 & 0,42029 \\
\hline
\end{tabular}


The order of variants when using the TOPSIS method is:

1. Realme 7i,

2. Xiaomi Redmi Note 10,

3. Samsung Galaxy A52,

4. Xiaomi Mi Note 10 Lite,

5. Samsung Galaxy A42.

\subsection{Weighted sum method}

After determining the ideal variant $\mathrm{h}=(-3299,64,128,6144,11,-179,6000)$ and the basal variant $\mathrm{d}=(-8990,48,64,4096,10,-208,4500)$, a standardized criterion matrix is calculated. Finally, the value of the utility function is calculated for each variant, according to which the variants are subsequently sorted.

Table 6. Utility function of individual variants

\begin{tabular}{|l|r|}
\hline Type of mobile phone & Utility function \\
\hline Samsung Galaxy A42 & 0,41129 \\
\hline Xiaomi Mi Note 10 Lite & 0,48973 \\
\hline Xiaomi Redmi Note 10 & 0,48877 \\
\hline Realme 7i & 0,30435 \\
\hline Samsung Galaxy A52 & 0,65817 \\
\hline
\end{tabular}

The order of variants when using the weighted sum method is:

1. Samsung Galaxy A52,

2. Xiaomi Mi Note 10 Lite,

3. Xiaomi Redmi Note 10,

4. Samsung Galaxy A42,

5. Realme 7 i.

\section{Conclusions and discussion}

Of the methods requiring ordinal information, the lexicographic method and the ORESTE method were applied. These methods rank the variants from best to worst. The order of the variants arranged according to these two methods in the model example differed significantly in some variants.

The lexicographic method recommended buying the cheapest variant. On the contrary, the most expensive variants were awarded the last places in the order. The advantage of this method lies in its ease of use. On the contrary, the disadvantage is the complete neglect of less important criteria. As the number of criteria in a task increases, more criteria are neglected, making it more suitable for use with less extensive decision-making problems. The ORESTE method recommended buying one of the most expensive variants. On the contrary, it placed the cheapest variant in the last place. The other variants ranked both methods more or less the same. The reason for placing the Samsung Galaxy A52 mobile phone in the first place is the fact that this phone is rated better than the other variants in other criteria. The advantage of the ORESTE method over the previous method is the inclusion of all variant values in the criteria in the calculation. The disadvantage of the method is to obscure the differences between the values of the variants in the criteria, because the individual values are evaluated by serial numbers. 
Of the methods requiring cardinal information, the TOPSIS method and the weighted sum method were applied. Both of these methods arranged the variants significantly differently. The TOPSIS method in the model example recommended the purchase of the Realme 7i variant, but the difference between the first and second place is not significant. Both variants had a similar distance from the ideal variant, but the first variant had a greater distance from the basal variant. The most significant difference in the relative distance index is be-tween the second and third place.

The weighted sum method recommended the purchase of the Samsung Galaxy A52 variant despite its high price. This is due to the fact that most of its parameters are among the best and were rated 1 in the standardized matrix R. Conversely, this method placed the cheapest variant of Realme $7 \mathrm{i}$ last due to their worse values in the other criteria, which were rated zero in the standardized matrix.

All the above results were calculated using the Decision Support System. The application contains a DLL library, which provides the decision-making process and the structure of the decision problem, and the user environment. The DLL can not only be used by the Decision Support System, but can also be the basis for another new decision support system. As a possible extension of this library, it is proposed to add other decision methods or to add criteria weights using methods based on pairwise comparisons.

\section{Acknowledgements}

The paper was supported by institutional support of University of Pardubice. The work was supported by the internal project SPEV - Economic Impacts under the Industry 4.0 / Society 5.0 Concept, 2020, University of Hradec Králové, Faculty of Informatics and Management, Czech Republic. Thanks for help to Martin Kral.

\section{References}

1. Bažant, M. (2009). Řešení vybraných provoznich problémů osobni železniční stanice v rámci simulačního modelu. Univerzita Pardubice, Dopravní Fakulta Jana Pernera.

2. Brožová, H., Šubrt, T., \& Houška, M. (2003). Modely pro vícekriteriální rozhodování. Credit. Česká zemědělská univerzita v Praze, Katedra operační a systémové analýzy.

3. Büyüközkan, G., \& Güleryüz, S. (2016). Multi Criteria Group Decision Making Approach for Smart Phone Selection Using Intuitionistic Fuzzy TOPSIS. International Journal of Computational Intelligence Systems, 9(4), 709-725.

4. Chang, C.-W., Hsiao, H.-Y., Tang, C.-H., Chuang, Y.-J., \& Lin, C.-Y. (2010). DesignBased Guidelines for the Semantic Perception of Emergency Signs. Journal of Psycholinguistic Research, 39(1), 21-33.

5. Datart. (2021). https://www.datart.cz/

6. Fiala, P. (2008). Modely a metody rozhodování. Oeconomica, Vysoká škola ekonomická v Praze, \& Fakulta informatiky a statistiky.

7. Han, S. H., Kim, K. J., Yun, M. H., Hong, S. W., \& Kim, J. (2004). Identifying mobile phone design features critical to user satisfaction. Human Factors and Ergonomics in Manufacturing, 14(1), 15-29. 
8. Heureka. (2021). Heureka-Mobilní telefony. https://mobilnitelefony.heureka.cz/samsung-galaxy-a42-a426b-5g-6gb-128gb-dual-sim/

9. Işılar, G., \& Büyüközkan, G. (2007). Using a multi-criteria decision making approach to evaluate mobile phone alternatives. Computer Standards \& Interfaces, 29(2), 265274.

10. Lee, Y. S., Hong, S. W., Smith-Jackson, T. L., Nussbaum, M. A., \& Tomioka, K. (2006). Systematic evaluation methodology for cell phone user interfaces. Interacting with Computers, 18(2), 304-325.

11. Lysonski, S., Durvasula, S., \& Zotos, Y. (1996). Consumer decision-making styles: A multi-country investigation. European Journal of Marketing, 30(12), 10-21.

12. Mourtzis, D., Doukas, M., \& Vandera, C. (2017). Smart mobile apps for supporting product design and decision-making in the era of mass customisation. International Journal of Computer Integrated Manufacturing, 30(7), 690-707.

13. Plos, O., \& Buisine, S. (2006). Universal design for mobile phones: A case study. CHI '06 Extended Abstracts on Human Factors in Computing Systems - CHI EA '06, 1229.

14. Stankevich, A. (2017). Explaining the Consumer Decision-Making Process: Critical Literature Review. Journal of international business research and marketing, 2(6), 7 14.

15. Zapletal, F. (2020). On Importance of Performance Values for Preference Degrees in PROMETHEE . 38th International Conference on Mathematical Methods in Economics, $662-668$. 